\title{
Study on Aluminium Contamination in Mettur soil and Its Subsequent Uptake by Medicinal plants
}

\section{KALPANA PALANI ${ }^{1}$, KRISHNAMURTHY BALASUBRAMANIAN ${ }^{2}$ and R. A. KALAIVANI ${ }^{3 *}$}

${ }^{1}$ School of Basic Sciences, Vels Institute of Science, Technology and Advanced Studies (VISTAS), Chennai, India ${ }^{2}$ National Agro Foundation, Taramani, Chennai, Tamil Nadu, India.

${ }^{3}$ School of Basic Sciences, Vels Institute of Science, Technology and Advanced Studies (VISTAS), Chennai, India

${ }^{*}$ Corresponding author E-mail: rakvani@yahoo.co.in

http://dx.doi.org/10.13005/ojc/340659

Received: August 27, 2018; Accepted: November 28, 2018)

\begin{abstract}
Nowadays, the use of medicinal plants for disease treatment has been limited due to widely prevailing toxicity of medicinal plants and their source soil. The major reason for the toxicity in plants might be due to their mineral and chemical content and also related with the toxic materials present in the source soil. The aim of this study was to assess the aluminum contamination in Mettur, an industrial town of Tamil Nadu, India which has many Al industries. Total Al content in the soil of the region where medicinal plants were cultivated was found to be $16700 \mathrm{mg} \mathrm{kg}^{-1}$. Further, Al content in commonly used medicinal plants Centella asiatica, Bacopa monneri and Euphorbia hirta grown in Al polluted soil was studied. The Al concentration of the medicinal plants ranged from 449 to $801 \mathrm{mg} \mathrm{kg}^{-1}$. All the three plants were found to accumulate level of Al which is above the maximum permissible limits prescribed by World Health Organization and thus, it may cause Al toxicity among the consumers of herbal medicines. From the results of the present study, it is inferred that the medicinal plants used for the human consumption or disease management should be collected from clean environment and processed carefully.
\end{abstract}

Keywords: Medicinal plants, Soil contamination, Aluminium, Heavy metals.

\section{INTRODUCTION}

Medicinal plants have found extensive use in disease management and its allied fields. According to the world health organization report ${ }^{1}$, it is estimated that 65 to $80 \%$ of the world's population depending on various medicinal plants for their healthcare and related activities. Nowadays, the use of medicinal plants for disease treatment has been limited due to widely prevailing toxicity of medicinal plants and their source soil. The major reason for the toxicity in plants might be due to their mineral and chemical content and also related with the toxic materials present in the source soil ${ }^{2}$. So they may cause serious impact if consumed beyond the safer uptake limit. Though several researchers have reported on the physiological, chemical and biological properties of medicinal plants, very

This is an Open Access article licensed under a Creative Commons license: Attribution 4.0 International (CC- BY). Published by Oriental Scientific Publishing Company @ 2018 
meager work have been reported regarding the heavy metal toxicity in medicinal plants. The quality of herbal medicine may be affected due to the presence of heavy metal caused by the extensive contamination of environment. Evaluation and continuous monitoring of heavy metal contamination is an important measure for the improvement of safety and quality of medicinal which has been widely used for the preparation of herbal medicines. There by we can enhance the health status of patients or consumers. More over heavy metals also affect the production of secondary metabolites in medicinal plants which the major deciding factor for their usage in preparation of herbal medicines ${ }^{3}$.

From the past scenario, it is noted that the industrial activities related to mining and smelting caused severe heavy metal contamination in the environment. It also increased the concentration of metals in the soil, air and water ecosystem. Thus, it enters in to the food chain and becomes a major threat to the humans, animals and plants through biomagnification process. The concentration of heavy metals present in medicinal plants and spices exceed the safer limit especially if they grown or collected from pollutes sites ${ }^{4}$. Apart from the laboratory study on phytoextraction of heavy metals in plants ${ }^{5}$, it is also important to evident the correlation between metal levels in plants and the soil in which these plants grow. In the present investigation, we focused on soil aluminium pollution in the Mettur area. It is also called aluminium city of Tamilnadu, having Aluminium plant Called MALCOMadras Aluminium Company Ltd, Steel industry, Chemplast Sanmar/Mettur Chemicals. Since, it is a place surrounded with aluminium industries, there is a possibility of more aluminium pollution in soil6.

Aluminium is the third most abundant element in the earth's crust. It may cause toxicity to the plants especially when it is solubbilised in acidic soils ${ }^{7}$. There is limited research regarding the uptake of $\mathrm{Al}$ by plants ${ }^{8}$. It is well known that accumulation of $\mathrm{Al}$ in plants is affected by mobile and potentially bioavailable forms of Al present in soils ${ }^{9}$. Hence, an attempt has been initiated to study the content of aluminium in soil and further its accumulation in few medicinal plants such as Centella asiatica, Bacopa monneri and Euphorbia hirta grown in Mettur area.

\section{MATERIALS AND METHODS}

The experimental site Mettur is located in Salem, Tamil Nadu, India. The latitude and longitude coordinates of Mettur is $11.80 \mathrm{~N} \mathrm{77.80E}$ with the elevation of $238 \mathrm{~m}$. Since Mettur is an area having several steel and aluminium processing industries, there is a possibility for aluminium contamination in soil and subsequent translocation in plant tissues. Hence, in present study, an attempt was made to investigate the amount of aluminium present in Mettur soil and further translocation of aluminium in few medicinal plants such as Centella asiatica, Bacopa monneri and Euphorbia hirta.

The soil samples and plant samples of such as Centella asiatica, Bacopa monneriand Euphorbia hirta were collected from Mettur area. The soil sample was analysed for initial parameters such as soil pH, EC, organic matter, available macro, secondary and micronutrients along with aluminium content using standard methods. The collected plant samples were cleaned with water and kept in paper covers. Then they were shade dried and later oven dried $\left(70^{\circ} \mathrm{C}\right)$. After recording the dry weight, each sample was ground in a Wiley mill and sub-samples were obtained for laboratory analysis. The total aluminium content in the plant materials was determined using an Atomic Absorption Spectrophotometer with air-acetylene flame. Finally the bioconcentration factor for each plant was calculated.

\section{RESULTS AND DISCUSSION}

The soil and plants samples were collected from Mettur and analysed for aluminium contamination along with other parameters. The results are presented below.

\section{Initial characteristics of soil}

The soil sample collected from Mettur area was analysed for different basic parameters and presented in Table 1. The $\mathrm{pH}$ of the soil was acidic and EC was not harmful. While considering the status of macro nutrients, nitrate nitrogen was high but the phosphorus and potassium levels were low. The secondary nutrients were also little bit lower in range. The micro nutrients such as zinc and copper were low whereas manganese, iron and boron were ideal in status. The Aluminium content of soil was $16700 \mathrm{mg} \mathrm{kg}^{-1}$ which is very high. 
Table 1: Initial Characteristics of Experimental Soil

\begin{tabular}{ccc}
\hline SI. No. & Parameter & Value \\
\hline 1 & $\mathrm{pH}$ & 5.73 \\
2 & EC $\left(\mathrm{mS} \mathrm{cm}{ }^{-1}\right)$ & 0.187 \\
3 & Organic Matter $(\%)$ & 1.23 \\
4 & Nitrate-Nitrogen $\left(\mathrm{mg} \mathrm{kg}^{-1}\right)$ & 50.8 \\
5 & Phosphorus $\left(\mathrm{mg} \mathrm{kg}^{-1}\right)$ & 15.27 \\
6 & Potassium $\left(\mathrm{mg} \mathrm{kg}^{-1}\right)$ & 80 \\
7 & Calcium $\left(\mathrm{mg} \mathrm{kg}^{-1}\right)$ & 841 \\
8 & Magnesium $\left(\mathrm{mg} \mathrm{kg}^{-1}\right)$ & 354 \\
9 & Sulphur $\left(\mathrm{mg} \mathrm{kg}^{-1}\right)$ & 38.8 \\
10 & Sodium $\left(\mathrm{mg} \mathrm{kg}^{-1}\right)$ & 138 \\
11 & Zinc $\left(\mathrm{mg} \mathrm{kg}^{-1}\right)$ & 0.92 \\
12 & Manganese $\left(\mathrm{mg} \mathrm{kg}^{-1}\right)$ & 21.78 \\
13 & Iron $\left(\mathrm{mg} \mathrm{kg}^{-1}\right)$ & 26.07 \\
14 & Copper $\left(\mathrm{mg} \mathrm{kg}^{-1}\right)$ & 1.60 \\
15 & Boron $\left(\mathrm{mg} \mathrm{kg}^{-1}\right)$ & 1.6 \\
16 & Aluminium $\left(\mathrm{mg} \mathrm{kg}^{-1}\right)$ & 16700 \\
\hline
\end{tabular}

The experimental soil collected from Mettur area contains low level of macro, secondary and micro nutrients. The soil is acidic along with the high range of aluminium content. The soil toxicity in acid soils may be contributed by several factors and it mainly depends in the soil composition. Aluminium toxicity is the prime factor which is limiting the plant growth in acid soils. Generally in acidic soil, Al occurred as $\mathrm{Al}(\mathrm{OH})^{2+}, \mathrm{Al}(\mathrm{OH})$ and $\mathrm{Al}\left(\mathrm{H}_{2} \mathrm{O}\right)^{3+}$, the latter referred to as $\mathrm{Al}^{10}$. Even at micromolar level, $\mathrm{Al}$ ions inhibit the root growth of agricultural crops. It also causes stunting of the primary root and inhibition of lateral root formation. Inhibition of cell elongation and cell division resulting in stubby root tips. Finally it is impaired in the uptake of nutrient and water, then plant becomes more susceptible to drought stress. The yield and crop quality of Al sensitive plants have greatly affected due to Al toxicity ${ }^{11,12}$. It is evident that the distribution and availability of some elements to plants in vetisols might be affected by the physical-chemical characteristics of soil ${ }^{13}$. The very low phosphorus content in the soil is mainly due to the fixation of phosphorus as aluminium phosphate. The presence of free alumina is mainly responsible for phosphorus fixation ${ }^{14}$.

\section{Plants used in this experiment}

Few medicinal plants were collected from the sampling site (Mettur area), processed and analyzed for aluminium content. The detail of the plants used is given in Table 2.

Table 2: Detail of plants used in the study

\begin{tabular}{cccc}
\hline SI. No. & Common Name & Botanical Name & Family \\
\hline 1 & Asiatic pennywort & Centella asiatica & Apiaceae \\
2 & Brahmi or Indian pennywort & Bacopa monneri & Plantaginaceae \\
3 & Asthma Weed & Euphorbia hirta & Euphorbiaceae \\
\hline
\end{tabular}

From the past centuries, medicinal plants play a major role in the preparation of traditional medicine as well as home remedies. The contamination of medicinal plants occurred due to heavy metals and microbial growth. It depends on the number of factors such as environment, pollution, atmosphere, soil, harvesting and handling etc. Therefore, it is essential that the measurement of metallic elements in medicinal plants and also establishment of safety limit for these elements since it has been consumed along with the herbal medicines ${ }^{15}$.

\section{Concentration of aluminium and bioaccumulation factor of selected medicinal plants}

The medicinal plants such as Centella asiatica, Bacopa monneriand Euphorbia hirta grown in the study area were collected and analysed for aluminium content and results are presented in Table 3.
Table 3. Concentration of aluminium and bioaccumulation factor of the medicinal plants grown in study area (Mettur)

\begin{tabular}{lccc}
\hline $\begin{array}{l}\text { S. } \\
\text { No }\end{array}$ & $\begin{array}{c}\text { Name of } \\
\text { the Plant }\end{array}$ & $\begin{array}{c}\text { Concentration } \\
\text { of } \mathrm{Al}\left(\mathrm{mg} \mathrm{kg}^{-1}\right)\end{array}$ & $\begin{array}{c}\text { Bioaccumulation } \\
\text { factor }\end{array}$ \\
\hline 1 & Centella asiatica & 747.8 & 0.04 \\
2 & Bacopa monneri & 449.6 & 0.03 \\
3 & Euphorbia hirta & 801.5 & 0.05 \\
\hline
\end{tabular}

The aluminium concentration was very high in Euphorbia hirta (801.5 $\left.\mathrm{mg} \mathrm{kg}^{-1}\right)$ followed by Centella asiatica ( $747.8 \mathrm{mg} \mathrm{kg}^{-1}$ ) whereas the lowest aluminium content was recorded in Bacopa monneri $\left(449.6 \mathrm{mg} \mathrm{kg}^{-1}\right)$. All the three plants showed a very high accumulation of aluminium due to the high level of aluminium in parent soil.

The bioaccumulation factor for each medicinal plant was calculated as per the following formula. 
$\mathrm{BAF}=\mathrm{C}_{\text {plant }} / \mathrm{C}_{\text {soil }}$

Where, $\mathrm{C}_{\text {plant }}$ and $\mathrm{C}_{\text {soil }}$ are the concentrations of heavy metal in plants and soil, respectively, on dry weight basis ${ }^{16}$. The bioaccumulation factor was high in Euphorbia hirta followed by Centella asiatica. Bacopa monneri recorded the lowest bioaccumulation factor when compared with other two plants.

Accumulation of heavy metal in plants from soil is the major pathway for the transformation of metals from sediments and water to the food chain by the mechanism called as biomagnifications. The translocation of metal from soil to plant is mainly decided by mobile and bioavailable fractions of metal. Plants can absorb metal from soil, accumulate in their parts and transform it from soils into the food chain. Phytoaccumulation of metal is one of the most serious environmental problem because of their potential harmful impact on animals and human health ${ }^{17}$. The Al toxicity in plants is primarily exhibited by several symptoms such as inhibition of root growth, variety of nutrient-deficiency symptoms and yield reduction etc ${ }^{18}$. Plant species that accumulate high concentrations of $\mathrm{Al}>1000 \mathrm{mg} / \mathrm{kg}$ ) in their tissues are regarded as a hyperaccumulators of these elements ${ }^{19,20}$. From the data in the present study, although all the three medicinal plants accumulated $\mathrm{Al}$, they cannot be classed as a hyperaccumulator of aluminium since the bioaccumulation factor is $<1$. These medicinal plants are widely used for the preparation of herbal medicine but showed higher Al content (Table 3). Eventhough the selected medicinal plants are not classed as hyperaccumulators, all the three medicinal plants such as Centella asiatica, Bacopa monneri and Euphorbia hirta were able to accumulate level of $\mathrm{Al}$ which was above the maximum permissible limits of $15 \mathrm{mg} / \mathrm{kg}^{21,22,23}$. Intake of high levels of Al through medicinal plants or other sources can impair cognitive and speech functions and may also lead to neurodegenerative diseases ${ }^{24}$. The accumulation of $\mathrm{Al}$ in the above medicinal plants from aluminium contaminated soil may raise the awareness regarding safety when they used as raw materials for the preparation if herbal medicine.

\section{CONCLUSION}

Procurement of the medicinal plants from the aluminium polluted soils and used for the preparation of traditional medicine raises some potential negative issues for the society. The accumulation of $\mathrm{Al}$ concentration is above the maximum permissible limit prescribed by WHO and thus, it may cause Al toxicity among the consumers of herbal medicines. The Al present in the medicinal plants may alter physiochemical properties of the plant so that to adapt under stress conditions. It may affect the synthesis of secondary metabolites or bioactive ingredients in medicinal plants. Subsequently the quality and efficacy of the medicine produced from the particular plants may be reduced due to the increased content of $\mathrm{Al}$ from the results of the present study, it is inferred that the medicinal plants used for the human consumption or disease management should be collected from clean environment and processed carefully. Furthermore, they may be tested for the presence of any contaminants before used as a raw material for the preparation of herbal medicine.

\section{ACKNOWLEDGEMENT}

Authors acknowledge the support from National Agro Foundation to carry out the analytical study at their R\&D Centre.

\section{REFERENCES}

1. WHO. WHO: Geneva Switzerland; Quality control methods for medicinal plant materials. available athttp://whqlibdoc.who.int/ publications/1998/9241545100.pdf., 1998.

2. Lekouch, N.; Sedki, A.; Nejmeddine, A.; Gamon, S. Sci. Total Environ., 2001, 280, 39-43.

3. Das, D.K. J. Pharm. Res., 2016, 15(3), 63-66.

4. Barthwal, J.; Nair, S.; Kakkar, P. Biomed. Environ. Sci., 2008, 21(4), 319-324.
5. Manousaki, E.; Kalogerakis, N. Environ. Sci. Pollut. Res. Int., 2009, 16, 844-854.

6. Krishnaveni, M.; Durairaj, S.; Madhiyan, P.; Amsavalli, L.; Chandrasekar, R. Int. J. Pharm. Sci.s Rev. Res., 2013, 20, 173-177.

7. Kochian, L.V. Annu. Rev. Plant Physiol. Plant Mol. Biol., 1995, 46, 237-260.

8. Kassaye, Y.A.; Salbu, B.; Skipperud, L.; Einset, L. J. Acta. Physiol. Plant., 2013, 35, 1749-1761. 
9. Vondrackova, S.; Szakova, J.; Drabek, O.; Tejnecky, V.; Hejcman, M.; Mullerova, V.; Tlustos, P. PLoS ONE., 2015, 10(4), 16-19.

10. Kinraide, T. Plant and Soil., 1991, 134, 167-178.

11. Samac, D.; Tesfaye, M. Plant Cell Tiss. Org., 2003, 75, 189-207.

12. Jovanovic, Z.; Djalovic, I.; Tolimir, M.; Cvijovic, M. Cereal Res. Commun., 2007, 35, 1325-1329.

13. Milivojevic, J.;Nikezic, D.; Krstic, D.;Jelic, M.; Djalovic, I. Pol. J. Environ. Stud., 2011, 20, 993-1000.

14. Sinha, P. R. J. Indian Chem. Soc., 1956, 33, 415.

15. Gajalakshmi, S.; Iswarya, V.; Ashwini, R.; Divya, G.; Mythili, S.; Sathiavelu, A. Eur. J. Exp. Biol., 2012, 5, 1457-1461.

16. Zhuang, P.; Li, Z.; Zou, B.; Xia, H.; Wang, G. Pedosphere., 2013, 23(3), 298-304.

17. Kabata-Pendias, A. \& Pendias, H., Trace Elements in Soils and Plants, $2^{\text {nd }}$ Edition, CRC Press, Boca Ratón, Florida., 1992, 315.
18. Shamsi, I.H.; Wei, K.; Jilani, G.; Zhang, G. J. Zhejiang Univ., B. 2007, 8, 181-188.

19. Baker, A.J.M.; Reeves, R.D.; Hajar, A.S.M. New Phytol., 1994, 127, 61-68.

20. Jansen, S.; Broadley, MR.; Robbrecht, E.; Smets, E. Bot. Rev., 2002, 68, 235-269.

21. Okem, A.; Stirk, W.; Street, R.; Southway, C.; Finnie, J.; Van Staden, J. Plant Physiol. Biochem., 2015, 97, 147-155.

22. National Research Council, Drinking Water and Health, vol. 4. National Academy Press, Washington, D.C., 1982.

23. World Health Organization, WHO Guidelines for Assessing Quality of Herbal Medaicines with Reference to Contaminants and Residues. WHO Publishers, Geneva., 2007.

24. Bolla, J.L.; Ross, A.H.; Spector, D.; Schwartz, B.S.; Wieler, L.; Herron, J.; Gimenez, L. Arch. Neurol., 1992, 4, 1021-1026. 